\title{
Lederstil kan avgjøre ansattes trivsel
}

Hvilken type lederstil sjefen har kan ha effekt på jobbtrivselen til de ansatte. I en nylig publisert studie har man sett på hvordan ulike lederstiler påvirker medarbeidere på kort og lang sikt.

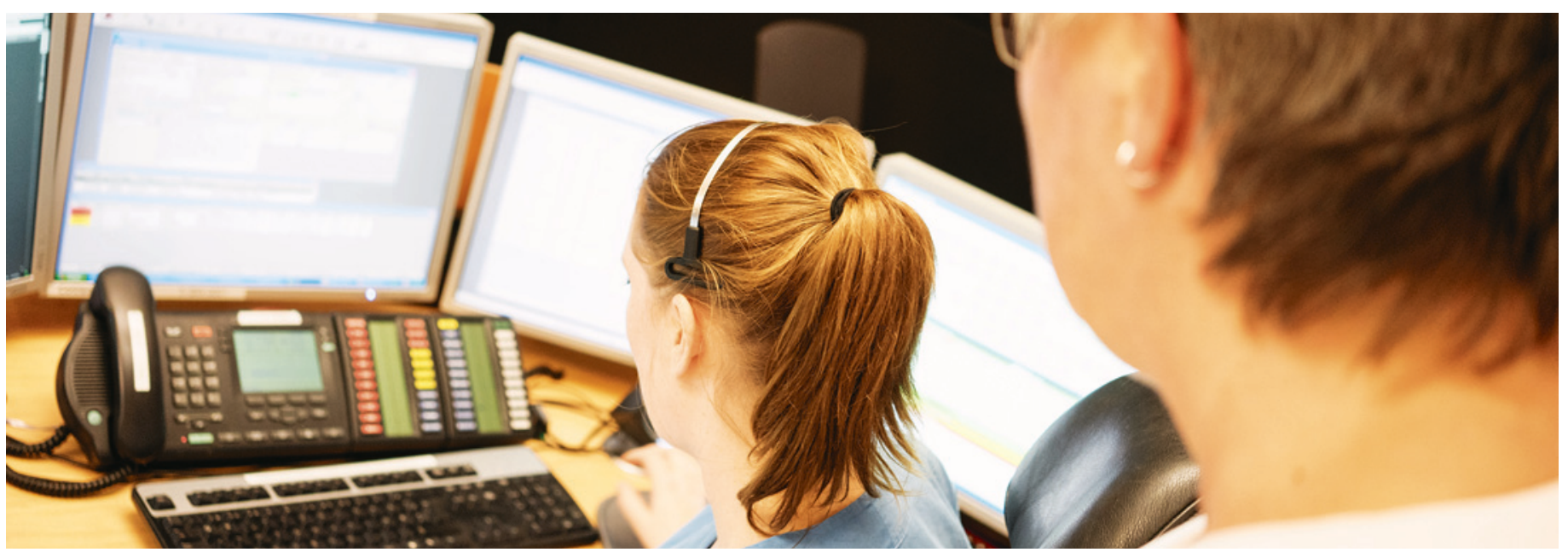

Illustrasjonsfoto: Ole Kristian Losvik

Studien, som er gjennomført av Statens arbeidsmiljøinstitutt (STAMI), skiller seg fra tidligere studier ved at man har sett på utviklingen over tid og funnet korttids- og langtidseffektene av de forskjellige stilene (1). I studien deles lederstiler inn i tre kategorier: Konstruktiv, laissez-faire og tyrannisk ledelse. De to sistnevnte grupperes som destruktiv lederstil.

\section{Hovedfunn}

Studien er basert på to longitudinelle undersøkelser. I den ene fylte offshorearbeidere ut spørreskjema med seks måneders mellomrom, mens den andre studien er basert på et representativt utvalg av norske arbeidere over to år (2).

Forskerne fant at destruktive lederstiler har en effekt på de ansatte, mens konstruktiv lederstil ikke har noen påvirkning på jobbtilfredshet, verken på kort eller lang sikt. Den tyranniske stilen ga en reduksjon i tilfredshet og trivsel blant de ansatte etter seks måneder, men viste ingen endring etter to år. Dette kan ha sammenheng med flere ting, for eksempel at destruktive ledere ikke får holde på slik over en lengre periode og blir korrigert av sine overordnede før det har gått så lang tid, skriver Morten Birkeland Nielsen ved Statens arbeidsmiljøinstitutt (2).

\section{Ulike former for ledelse}

Magma, medlemstidsskriftet til Econa, interesse- $o g$ arbeidstakerorganisasjonen for siviløkonomer og masterutdannede innen økonomisk-administrative fag, beskriver konstruktiv ledelse som ledere som ivaretar og utvikler mennesker og samtidig ser til at oppgaver blir utført (3). En leder med denne stilen arbeider for bedriftens mål, samtidig som medarbeidernes individuelle behov blir imøtekommet.

Med laissez-faire-ledelse menes at lederen «lar det skure og gå». Lederen er verken opptatt av menneskene i bedriften eller av oppgavene og bidrar ikke med noen form for styring i det hele tatt.

Det viser seg at én av tre slutter på grunn av sjefen (4). Den tyranniske stilen kjennetegnes ved at lederen utelukkende er opptatt av å nå bedriftens mål. Hun eller han er også tilbøyelig til å bakvaske og manipulere sine underordnede. Fordi en slik leder kan fremstå som effektiv og konstruktiv overfor sine overordnede, kan tyranniske ledere være vanskelig å slå ned på og forandre, skriver Magma.

\section{Elisabeth Jacobsen}

Tidsskriftet

\section{Litteratur}

1. Skogstad A, Aasland MS, Nielsen MB et al. The relative effects of constructive, laissez-faire, and tyrannical leadership on subordinate job satisfaction: Results from two prospective and representative studies. Zeitschrift für Psychologie 2014; 222: $221-32$

2. Statens arbeidsmiljøinstitutt. Konstruktiv og destruktiv ledelse på kort og lang sikt. www.stami.no/konstruktiv-og-destruktiv-ledelsepa-kort-og-lang-sikt (9.3.2015).

3. Nielsen MB, Aasland MS, Matthiesen SB. Destruktiv ledelse. Magma 2004; nr. 4. www.magma.no/ destruktiv-ledelse (9.3.2015)

4. Hvamstad E. Én av tre slutter på grunn av sjefen. Hegnar.no 13.5.2013. www.hegnar.no/okonomi/ artikkel326927.ece (18.2.2015).

\section{«Destruktive ledere får ikke holde på slik over en lengre periode»}

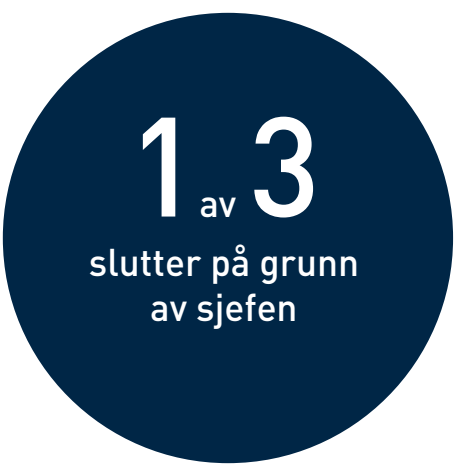

